Manuscript received 04.12.2020

Accepted: 03.02.2021

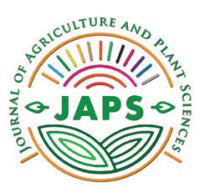

In print: ISSN 2545-4447

On line: ISSN 2545-4455

doi: https://doi.org/10.46763/JAPS18209gjk

Original scientific paper

\title{
INTRODUCING SUSTAINABLE RICE PRODUCTION TO IMPROVE ENVIRONMENTAL AND SOCIO- ECONOMIC CONDITIONS IN KOCHANI VALLEY
}

\author{
Marija Gjosheva Kovachevikj ${ }^{*}$, Verica Ilieva ${ }^{2}$, Saso Arsov ${ }^{2}$ \\ ${ }^{1}$ Nature Conservation Programme in North Macedonia, Farmahem, Kičevska 1, 1060 Skopje, \\ Republic of North Macedonia \\ ${ }^{2}$ Goce Delcev University, Faculty of Agriculture, Krste Misirkov 10-A, 2000 Stip, \\ Republic of North Macedonia \\ *Corresponding author: marija@bregalnica-ncp.mk
}

\begin{abstract}
Favourable climate conditions and the long tradition of rice cultivation as a main source of livelihood is essential base for a large portion of the population in the Kochani valley. The low productivity levels and high production costs put major limitations on the competitiveness on markets, mainly due to inadequate and obsolete cultivation practices applied. In addition, the common cultivation methods contribute to the destruction of environment and agroecosystems by intensive use of natural resources and agrochemicals. To that end, the NCP project implemented activities for adaptation of sustainable rice practices at 30 farmers, members in the association "Rice Tiller", Cheshinovo, for the period of three years (2017-2019). Primarily, sustainable rice practices used by farmers consisted of: laser land levelling, use of certified seed material and reduced seed quantity, controlled use of fertilizers and agrochemicals and controlled use of water. Two sowing variants are implemented and tested, one by using seeding machine on dry soil and the another with manual seed broadcasting onto the watered soil. In this paper, data gained from the farmers' passports, where regularly all agrotechnical measures and costs were recorded, are processed with the use of descriptive statistics and empirical methods of analysis. The outcomes demonstrate that the introduction of sustainable rice production results in efficient use of natural resources and reduced production costs, especially with dry-seeding method, which is fundamental for mitigation of food unsafety, biodiversity loss, soil degradation and environmental pollution, and at the same time for increasing rural households' revenues.
\end{abstract}

Keywords: natural resources, Gross Margin, Cobb-Douglas production function, technical efficiency, allocative efficiency

\section{INTRODUCTION}

Rice (Oryza sativa L.) has long tradition of cultivation in the Republic of North Macedonia. The favourable ecological conditions offer potential for high yield and quality rice production which can meet European and world quality standards (Ilieva et al., 2017). In all the cereals cultivated in the country, the rice share is around 3\% (llievski et al., 2015). Rice production has an important role in the country's economy, because not only does it provide sufficient supply for the domestic market, it is also an export-oriented industry
(Angelova et al., 2018). This can be seen from Tab. 1 where it shows that in the overall analyzed period of 5 years ( $2015-2019)$, the average total rice production ( 22,682 tons in average) covers the needs of the domestic market $(17,375$ tons in average) with $134 \%$ of average degree of selfsupply, enabling conditions for export as well. The export of rice quantity for the same period accounts 5,642 tons, with sharing of the import quantity in the total export by $6 \%$. 
Table 1. Supply and demand balance of rice in the North Macedonia, 2015 - 2019

\begin{tabular}{|l|r|r|r|r|r|r|}
\hline Year & \multicolumn{2}{|l|}{$\mathbf{2 0 1 5}$} & $\mathbf{2 0 1 6}$ & $\mathbf{2 0 1 8}$ & $\mathbf{2 0 1 9}$ & \multicolumn{1}{l}{ Average } \\
\hline Production (tons) & 30,527 & 24,792 & 17,080 & 19,732 & 21,278 & 22,682 \\
\hline $\begin{array}{l}\text { Import (tons) } \\
\text { I Total supply } \\
\text { (tons) }\end{array}$ & $\mathbf{2 0 , 7 7 4}$ & $\mathbf{2 4 , 9 9 7}$ & $\mathbf{1 7 , 5 1 4}$ & $\mathbf{1 9 , 9 3 3}$ & $\mathbf{2 1 , 8 6 9}$ & $\mathbf{2 3 , 0 1 7}$ \\
\hline $\begin{array}{l}\text { Domestic } \\
\text { consumption (tons) }\end{array}$ & 27,277 & 17,963 & 11,466 & 13,834 & 16,336 & 17,375 \\
\hline Export (tons) & 3,497 & 7,034 & 6,048 & 6,098 & 5,533 & 5,642 \\
\hline $\begin{array}{l}\text { II Total } \\
\text { consumption } \\
\text { (tons) }\end{array}$ & $\mathbf{3 0 , 7 7 4}$ & $\mathbf{2 4 , 9 9 7}$ & $\mathbf{1 7 , 5 1 4}$ & $\mathbf{1 9 , 9 3 3}$ & $\mathbf{2 1 , 8 6 9}$ & $\mathbf{2 3 , 0 1 7}$ \\
\hline $\begin{array}{l}\text { Degree of self- } \\
\text { supply (\%) }\end{array}$ & $\mathbf{1 1 2}$ & $\mathbf{1 3 8}$ & $\mathbf{1 4 9}$ & $\mathbf{1 4 3}$ & $\mathbf{1 3 0}$ & $\mathbf{1 3 4}$ \\
\hline
\end{tabular}

Source: SSO, 2020; SSO, Makstat-Database

The official statistics show that there is 4,067 ha on average planted area with rice for the period from 2015 till 2019, ranging from 5,018 ha in 2015 to 3,555 ha in 2019 , with the lowest values in 2018 (3,222 ha). The average yield for the same period accounts $5,699 \mathrm{~kg} / \mathrm{ha}$ with lowest value in 2016 which is $4,919 \mathrm{~kg} / \mathrm{ha}$ and highest in 2015 and 2018 with 6,124 kg/ha (Tab. 2).

Table 2. Sown area and average yields of rice production in the North Macedonia, 2015-2019

\begin{tabular}{|l|c|c|}
\hline Year & Sown area (ha) & Average yield of paddy rice (kg/ha) \\
\hline 2015 & 5,018 & 6,124 \\
\hline 2016 & 5,040 & 4,919 \\
\hline 2017 & 3,500 & 5,217 \\
\hline 2018 & 3,222 & 6,124 \\
\hline 2019 & 3,555 & 6,113 \\
\hline Average & 4,067 & 5,699 \\
\hline
\end{tabular}

Source: SSO, 2020

The size of the rice fields has a downward trend, especially when it is compared with rice planted areas in the past when the total rice fields accounted for more than 6,000 ha (e.g. there were 6,056 ha with rice in 1989 and 8,880 ha in 1990) (Andreevska et al., 2013). Regarding its location, rice is mainly concentrated in the Eastern part of the Republic of North Macedonia, along the course of the river Bregalnica, in the regions of Kochani, Shtip, Vinica and Blatec. It is also cultivated on smaller areas in the regions of Veles and Probishtip (Andreevska et al., 2018). The valley of Kochani belongs to the group of, so called, continental submediteranean areas, which are characterized by the most expressive translations of the Continental and Mediterranean climate and with high temperature amplitudes (Andreevska et al., 2013). The temperature sum during the rice vegetation in the Kochani region is in the frame from $2700^{\circ} \mathrm{C}$ to $4500^{\circ} \mathrm{C}$ (ibid). The essential growing conditions, such as heat, light as well the availability of irrigation water makes this area suitable for rice growing. In addition to this, high mountains on the border of the valley give it a special characteristic climate of this region adequate for rice production (ibid).

In terms of the variety structure, Macedonian rice varieties are little or not present at all, and the most common are Italian and Turkish varieties. From the Italian varieties, San Andrea is the most widespread, but also Galileo, Bianca, Brio, Ellebi, Opale, Arpa and Onice. From the Turkish varieties, farmers mostly plant Halilbey, Gala and Gonen (Andreevska et al., 2018).

In regard to common practices, the usual, traditional seeding method in the country is wet seeding into standing water (previously soaked seeds are manually broadcasted in 
water bed). These agricultural practices require high water consumption, high labour work, increased production costs, inadequate crop density with negative effects on the rice yield. Sowing by using seed drills on dry soil is not a common practice. Rice is usually grown on the same areas for many years without crop rotation (Andreevska et al., 2018) and high inputs of agrochemicals (Niswati, 2014). Land leveling of the rice fields is not commonly applied. The irrigation, which is by method of flooding, is continuous with periodical drainage and drying the rice field according to the needs for treatment of herbicides (Andreevska et al., 2013).

Beside the favourable soil and climate conditions, long tradition and economic significance of this agricultural product, rice growing is facing many challenges in the last several decades. High costs of agrochemicals for plant protection, fertilizers and high fuel price resulted in decrease of rice production and replacing it with another crops such as wheat, barley and corn. Other reasons for reduced rice cultivation are the environmental stresses, water scarcity and the ruined hidrosystem which has the main role for the agriculture in Kochani valley. Old agricultural machinery is also an important factor which limits the expansion of production, increases costs for depreciation and fuel and generates dificulties in land cultivation, harvesting and environmental pollution (Mihov et al., 2017). The competition on the international rice market is very strong, especially competition from Asian countires and causes market distortion on the rice produced in the country. Production of quality seed materials is also one of the crucial problems in the rice production, since there is no domestic production of the basic and lower seed categories, so the farmers either depend on imported certificate seed materials or use their own seed materials from the previous year, which results in lower yields (Младеновски et al., 2012). In order to encourage farmers to use certified seed materials, the state through direct subsidies provides additional support of $5,000 \mathrm{MKD} / \mathrm{ha}$ from the main support per ha $(25,000 \mathrm{MKD} / \mathrm{ha})$, if they provide and use this seed materials (AFSARD, 2020). Unfortunately, there has been no production of a certified seed material in the country for a longer period, therefore this direct payment measure is not commonly used by farmers. Because of that, one of the aims of the study is also to address this issue and to motivate farmers for using of better quality of seed materials. All these factors have negative socio-economic impact to farmers and causes abandoning of the rice fields and replacing rice with other crops. Also, many rice producers migrate from rural areas to cities or out of the country, or becoming employed in other industries in the place where they live. This is particularly evident among young farmers.

Continuous application of agrochemicals may damage the soil and cause decreased soil productivity and biodiversity, as well as increased pest attacks and methane emissions (Niswati, 2014). Various types of organisms live in wetland rice and each of them interacts with others to form a specific food chain (Ali, 1990; Roger et al., 1993). The conventional rice production what imply intensive use of agrochemicals, reduces the number of edible species traditionally harvested from rice fields, such as snails, prawns, crabs, large water bugs and frogs (Heckman, 1979). The direct or indirect effect of one organism on another will affect the community structure of the wetland rice organisms, which consist of nematodes, microcrustacea, protozoa, insect larvae, algae, mollusca, and oligochaetae (Mogi, 1993). As the organisms interact with each other, their populations are also affected by environmental factors, including fertilizer and pesticide application, water management, and crop variety (Simpson et al., 1994).

The agricultural practices which are usually adopted in flooded rice cultivation may have a significant impact on the environment (Ferrero \& Tinarelli, 2007). Besides its influence on the water use efficiency and grain yields, water management practices may also strongly alter hydrological regimes and soil moisture conditions, as a function of pedoclimatic conditions (Sacco et al., 2012; Zhao et al., 2015). Resulting changes in soil redox conditions are known to influence a variety of processes controlling nutrient distribution, transformation, losses, and bioavailability for rice crops (Cucu et al., 2014; Said-Pullicino et al., 2014), as well as greenhouse gas (GHG) production and emission to the atmosphere (Tyagi et al., 2010). Under flooded conditions significant amounts of nutrients (especially 
nitrogen, N) may be lost by leaching and runoff during the cropping season, with important implications on water quality (Katoh et al., 2004). These processes, together with the biotic and abiotic immobilization of $\mathrm{N}$ (Cucu et al., 2014; Said Pullicino et al., 2014) and gaseous losses into the atmosphere as $\mathrm{NH}_{3}, \mathrm{~N}_{2} \mathrm{O}$ and $\mathrm{N}_{2}$ via volatilization and nitrification/denitrification (Cassman et al., 1998) might strongly limit plant $\mathrm{N}$ availability and fertilizer use efficiency, consequently affecting yields (Nie et al., 2009).

Since production of rice usually requires large flooded areas, many greenhouse gases are generated which significantly contributes to global warming. Cultivation of rice is responsible for the release of carbon dioxide, methane, nitrogen oxides and its derivatives (de Miranda et al., 2015). Rice cultivation generally takes place in irrigated fields to maximize crop yields but constant water supply stimulates anaerobic soil environment formation which augments the methane $\left(\mathrm{CH}_{4}\right)$ emissions (Liu et al., 2013). In fact, rice paddy is the primary anthropogenic source of methane, accounting $11 \%$ of the total $\mathrm{CH}_{4}$ anthropogenic emissions (Smith et al, 2008).

Paddy fields are an important emission source of global Greenhouse Gas (Sun et al., 2016). However, good field management measures can greatly reduce agricultural Greenhouse Gas emission. Therefore, controlling and mitigating GHG emissions through reasonable agricultural measures is of great significance to mitigate climate warming (Liu et al, 2019).

The effects of rice production on biodiversity vary with production methods, which include fields managed organically or with agrochemicals and varied irrigation and planting systems and winter management regimes (Donald, 2004). Most rice is grown under flooded conditions so if they are managed appropriately, rice fields can provide habitats for wetland species and ecosystem services similar to those of natural wetlands (Katayama et al., 2015). The maintenance of flooded cropping systems can provide important ecosystem services such as the preservation of wetland habitats for a range of aquatic and semiaquatic wildlife, or of local traditional landscapes. Thus, knowledge of the advantages and disadvantages of each management practice can support the selection of the most appropriate one regarding the different local conditions (Miniotti et al., 2016).

Taking into consideration the importance of the rice production and numerous issues which rice ecosystems are currently facing, such as water scarcity, inefficient agronomical practices and its impact to the environment, three-year pilot project for introducing and adaptation of sustainable practices in rice production was conducted in Kochani valley, for improving of this subsector. The activities were supported by the Nature Conservation Programme in North Macedonia, project of the Swiss Agency for Development and Cooperation (SDC), coordinated by Farmahem, Skopje.

The objectives of this paper are:

- to examine the socio-economic characteristics of the rice farmers in the survey, as important factors for rice cultivation;

- to determine the production costs and revenues associated with wet and drydirect sowing practices;

- ascertain the level of allocative efficiency of the resource used in sustainable rice practices.

\section{MATERIAL AND METHODS}

\section{Study area}

The research was carried out in Kochani valley, in North Macedonia, where the rice is the largest and most important agricultural crop from economic and social aspects. The rice production in this valley is integral part of the tradition and heritage of the rural population, which is seen from the organising of the many traditional events and other ways to mark the significance of this crop (songs, recipes, different art competitions related to rice production and etc.). The rice is also called "Koschani's white gold" because of its high socio-economic value for these regions (NCP, 2014). In addition, the large rice fields in this valley, provide a valuable habitat for wide variety of amphibians and birds, especially for white storks, since they represent second largest population in Macedonia. So, the village Cheshinovo-Obleshevo which is located in this region and is part of the study area, was 
granted the honor of being declared a stork village in 2013 by EuroNature and become a part of the European Stork Village network. These indicate the high importance of the rice to remain the dominant crop in this region and to be further developed.

\section{Data Collection and sampling method}

This research is based on primary and secondary source of data. To achieve the aim of the research, data from the passport records of 30 farmers, involved in the activities for adaptation of sustainable rice practices, members of the association "Core group for sustainable rice production - Rice Tiller, Cheshinovo", were collected and processed. The survey refers to the production period from 2017-2019, conducted under constant consultation and observation by national and international rice experts. The research was conducted with Italian rice variety San Andrea, which is medium early variety, with medium long grain and in the recent years has dominant role in the rice production in North Macedonia (Ilieva et al. 2014). Applied sustainable rice practices used by farmers in the survey mainly are consisted of: land levelling; use of certified seed material and reduced seed quantity; controlled use of fertilizers, protective agrochemicals and water. Two sowing variants were implemented and tested: one by using seeding machine on dry soil and the another with manual seed broadcasting onto the watered soil.

Applying of the methods of sustainable rice production was performed on a total of 40 plots with an average size of 0.44 ha each by applying of sustainable practices, of which 30 plots were sown with manual seed broadcasting onto the watered soil and 10 plots by using seeding machine on dry soil. The number of plots with direct machine sowing is less than the number of plots with manual sowing because the farmers had difficulties in accepting and believing in success of the application of the first method. Irrigation is by method of flooding irrigation. Due to the great importance of efficient use of water as a natural resource, water measuring tubes were used to monitor water depth in the plots, recorded by the farmers every 7 days. Official statistics data and data from NEA (National Extension Agency) were used as reference data source.

\section{Analytical Technique}

Simple descriptive statistics such as frequency distribution, mean (M), maximum (Max), minimum (Min), standard deviation (SD) and coefficient of variation (CV) were used to describe socio-economic characteristics of the rice farmers in the study area. Lower values of the $\mathrm{CV}$, as a relative measure, indicate lower deviation in the sample from the arithmetic mean, and vice versa (Ристески, 1999).

In order to determine the costs and return, gross margin (GM) analysis was calculated for the both sowing systems, wet and dry.

$\mathrm{GM}=\mathrm{GR}-\mathrm{TVC}$ (Миланов \& Мартиновска, 2002)

\section{GM - Gross Margin \\ GR - Gross Return \\ TVC - Total Variable Cost}

\section{Production function}

The Stochastic Frontier Production function (SFPF) using the Cobb -Douglas functional form was used to determine the production function in this study. This functional form has been used in other empirical studies (Adedoyin, et al.; Izekor, 2015; Najjuma et al., 2016; Grazhdaninova \& Lerman, 2005; Oluwatusin, 2011) to assess both technical and allocative efficiencies. To estimate Cobb - Douglas production function econometrically, SPSS has been employed.

In general, the Cobb-Douglas production form is specified as follows:

$$
Y=\beta_{0}+\beta_{1 \times 1}+\beta_{2 \times 2}+\beta_{3 \times 3}+\beta_{4 \times 4}+\beta_{5 \times 5}+\varepsilon i
$$

This production function model was converted to its linear form by taking the logarithms:

$$
\ln Y=\ln \beta_{0}+\ln \beta_{1 \times 1}+\ln \beta_{2 \times 2}+\ln \beta_{3 \times 3}+\ln \beta_{4 \times 4}
$$
$+\ln \beta_{5 \times 5}+\varepsilon i$

Where:

In - Natural Logarithm

$\mathrm{Y}-$ Quantity of rice produced $(\mathrm{kg} / \mathrm{ha})$

$\mathrm{X}_{1}$ - Seed material $(\mathrm{kg} / \mathrm{ha})$

$\mathrm{X}_{2}$ - Mechanized hours (h/ha)

$X_{3}$ - Fertilizers $(\mathrm{kg} / \mathrm{ha})$

$\mathrm{X}_{4}$ - Chemical protection (I/ha)

$X_{5}$ - Water used (mm/ha)

$\mathrm{B}_{0}$ - Intercept term (scale parameter)

$\beta_{1}, \beta_{2}, \beta_{3,} \beta_{4}$ and $\beta_{5-}$ regression coefficients referred to $X_{1} X_{2} X_{3} X_{4}$ and $X_{5}$ inputs respectively. $\varepsilon_{i}$ - Composite error term independently distributed with zero mean and finite variance.

The sum of the estimated coefficient $\beta_{1}, \beta_{2}$, $\beta_{3,} \beta_{4}$ and $\beta_{5}$, gives information about returns to scale.

If the sum is 1 , then there are constant returns to scale, (e.g. doubling the inputs will 
double the output). If the sum is less than 1 , there are decreasing returns to scale (e.g. doubling the inputs will less double the output). If the sum is greater than 1 , there are increasing returns to scale (e.g. doubling the inputs will more than double the output).

\section{Determining Technical Efficiency (TE) of} Resource Use

The concept of TE relates to the question of whether a farm household uses the best available technology in its production process. TE means producing the maximum amount of output with the incorporation of minimum possible amount of inputs. Technical inefficiency arises when less than the maximum output is obtained from a given package of factors. Elasticity of production was used which is the percentage change in output as a ratio of a percentage change in input use (Elias, 2017; Grazhdaninova \& Lerman, 2005; Konj, 2019; Charnes, 1978).

Where:

$$
E P=\frac{M P P}{A P P}
$$

EP - Elasticity of production

MPP - Marginal Physical Product

APP - Average Physical Product

The Marginal Physical Product for each input is calculated by:

$$
M P P=\frac{\beta_{i} * y}{x_{i}}
$$

$B_{i}$ - regression coefficient

$\mathrm{Y}$ - geometric mean of output

$X_{\text {- }}$-geometric mean of input $X_{i}$

The Average Physical Product (APP) for each input is calculated by: ${ }_{A P P} \frac{y}{x_{i}}$
$Y$ - geometric mean of output

$X_{i}$ - geometric mean of input $X_{i}$

If:

$E P=1$, constant return to scale;

$E P<1$, decreasing return to scale;

$E P>1$, increasing return to scale.

Determining Economic Efficiency (EE) of Resources Use

Efficiency of resource input used was determine by the ratio of the Value of the Marginal Product (VMP) to Marginal Factor Cost (MFC). The relationship (as indicated by Izekor (2015), Goni et al., (2007), Tambo \& Gbemu (2010) is given as: $A P P \frac{y}{x_{i}}$

The Marginal Physical Product (MPP) for each of the production inputs was estimated from the regression coefficient of the Stochastic Frontier Production function (SFPF) using the Cobb-Douglas functional form, and was used to determine the Value of the Marginal Product (VMP). The value of the VMP is estimated as:

$\mathrm{VMP}=\mathrm{MPP} * \mathrm{Py}$

MPP - Marginal Physical Product

$\mathrm{P}_{y}$ - Average Unit price of output

If:

$r=1$, resource is efficiently utilised;

$r>1$, resource is under-utilized;

$r<1$, resource is over-utilized.

The allocative efficiency was used in order to measure the ability of the farmers for sustainable rice production in achieving the best combination of different inputs in producing at given level of output considering the relative prices of these inputs.

\section{RESULTS AND DISCUSSION}

Socio-economic characteristics of the rice farmers

The socio-economic analysis gave base to describe the typical characteristics of the rice households in this region such as: age and gender structure of the farmers, household size, farm size, farming experience and educational level of the farm holder. In average, a rice farm has 6.1 ha with land used for rice production, ranging from 0.5 ha to 30 ha, with a high coefficient of variation of $101 \%$, which indicates a large deviation from the mean (Tab. 3). 
Table 3. The Socio-economic characteristics of the rice producers, 2019

\begin{tabular}{|l|r|r|r|r|c|}
\hline Variable & Average & Maximum & Minimum & $\begin{array}{c}\text { Standard } \\
\text { deviation }\end{array}$ & $\begin{array}{c}\text { Coefficient of } \\
\text { variation (\%) }\end{array}$ \\
\hline Age (years) & 50.7 & 75.0 & 20.0 & 15.4 & 30.0 \\
\hline Household size (ha) & 4.5 & 8.0 & 2.0 & 1.7 & 37.2 \\
\hline Farm size (ha) & 6.1 & 30.0 & 0.5 & 6.2 & 101.0 \\
\hline $\begin{array}{l}\text { Farming experience } \\
\text { (years) }\end{array}$ & 32.5 & 60.0 & 7.0 & 16.7 & 51.0 \\
\hline
\end{tabular}

Source: field survey

The average size of family farms on national level is approximately 1.8 ha (SSO, 2017), and according to the data from the last agricultural census, the share of agricultural holdings with a rice land size from 5 to 8 ha accounts for approximately $18 \%$ of the total rice producers, and the highest share have agricultural holdings with size of the rice fields from 1 to 3 ha (25\%) (SSO, 2008). This implies that larger percentage of the rice farmers in the survey produce rice on a farm size bigger than the national average, what is very important for their productivity, but for the other side the level of fragmentation is very high accounting from 4 to 10 parcels (field survey). Many studies demonstrate that the loss in profitability is generally larger for small farms than for large farms, as small farms use more labor and other inputs than large farm households to earn higher rice income and profit (Mottaleb \& Mohanty, 2014).

In terms of age of rice farmers, the average is 50.7 (Tab. 3), ranging from 20 to 75 years, with $30 \%$ of coefficient of variation, of which around $1 / 3$ are with more than 60 years (Tab. 4). Compared to Greece, as rice producing country, the average age of rice farmers is 46 years and most of them are between 40 and 60 years old (Petri, 2016). Similar figures are also evidenced in Portugal, where large portion of farmers are in the age group of 40-50, with an age mean of 48.92 years (Chiambo, 2019). This implies that the rice production in North Macedonia is managed by elderly farmers as youth outmigration increases in the agricultural sector. Bad economic conditions, in which people live, insufficient development of the industry, possibilities for better life and better education, are only part of the reasons which cause greater migration, i.e. emigration of youth population from this region (NCP, 2014). According to many studies, the younger farmers are more likely to adopt new innovations to increase efficiency level than the older ones in production (Mabe et al., 2018; Onubuogu et al., 2014). The average number of members of the interviewed households, which influence the productivity, efficiency and value of the labor force, accounts 4.5. Since the household's holders are older and the number of members is relatively low, rice producers are likely to depend more on hired labor for production activities.

Data in the Tab. 3 also shows that average farming experience is 32.5 years, implying a reasonable level of specialization and expertise in rice production. The research revealed that out of the total surveyed farms, there are only 2 women (7\%) which are farm holders (Tab. 4). This indicates very low level of gender equality in terms of ownership. Majority of the farmers attained secondary school sharing $70 \%$ from the total number of the farmers in the survey, $20 \%$ has tertiary school and $10 \%$ primary school (Tab. 4). 
Table 4. Frequency of some of the socio-economic characteristics of the rice producers, 2019

\begin{tabular}{|l|c|c|}
\hline & \multicolumn{2}{|c|}{ Frequency } \\
\hline Gender & 28 & 93 \\
\hline Male & 2 & 7 \\
\hline Female & 30 & 100 \\
\hline Total & 9 & 30 \\
\hline Age (years) & 11 & 37 \\
\hline Less than 39 & 10 & 33 \\
\hline Between 40-59 & 30 & 100 \\
\hline More than 60 & 0 & 0 \\
\hline Total & 3 & 10 \\
\hline Educational level & 21 & 70 \\
\hline No formal education & 6 & 20 \\
\hline Primary school & 30 & 100 \\
\hline Secondary school & \multicolumn{2}{|c|}{} \\
\hline Tertiary education & \multicolumn{2}{|c|}{} \\
\hline Total & \multicolumn{2}{|c|}{} \\
\hline
\end{tabular}

Source: field survey

\section{Production costs and revenues}

The average yield of paddy rice per unit area amounts $8,019 \mathrm{~kg} / \mathrm{ha}$ and farmers received paddy price of $20 \mathrm{MKD} / \mathrm{kg}$ in average (Tab. 5). Average yields in the research are higher by $30 \%$ compared with official statistics (Tab. 2), with average yield of $5.699 \mathrm{~kg} / \mathrm{ha}$, but very close to the NEA data. With regards to the different variant of sowing, $4 \%$ of higher yield are realized at rice production with dry sowing accounting $8,255 \mathrm{~kg} / \mathrm{ha}$ in average, similar with finding of Andreevska et al. (2018). The major reasons for these results may be due to using certified seed materials, which influence to increased grain yield, enhanced crop growth and also reduced damage from weeds, insect pests and diseases (Haque et al., 2012). In addition, with land levelness, water coverage of the fields is even, what leads to: positively influence to the plant establishment, less weed problems, even crop stands, even ripening and even yields within each field. Good and less intensive management of pesticides (Tam, 2016) and fertilizers (Singh, 2017) also have contributed to better rice yields.
Regarding the structure of the variable costs, the costs for seed material have the largest share $(37 \%)$, followed by the costs for soil cultivation (27\%), fertilization costs $(16 \%)$, costs for protection of rice fields (14.5\%) and the lowest are the costs for water consumption $(0.11 \%)$. In general, the variability costs are lower for dry sowing compared to water sowing, except for the costs for mechanized hours (less costs for seed materials by $25 \%$, for fertilizer by $5 \%$, for chemical protection by $27 \%$, and higher costs for mechanization by $14 \%)$. Consequently, the values of the gross margin in dry sowing is higher for 19\% compared to wet sowing (MKD 80,735 at water sowing and MKD 96,062 at dry sowing). Similar results were obtained with the costs for production per $\mathrm{kg}$ rice at the variable costs level, with $10 \mathrm{MKD} / \mathrm{kg}$ average costs at wet sowing, and $8.59 \mathrm{MKD} / \mathrm{kg}$ at the production with dry sowing. Average share of variable costs from total revenues accounts $45 \%$, and share of gross margin from total revenues are 53\%, with better results for dry sowing. The obtained average indicators from the survey are close to data from NEA (Tab. 5). 
Table 5. Production costs and revenues of rice production

\begin{tabular}{|c|c|c|c|c|}
\hline Indicator & Wet sowing & Dry sowing & $\begin{array}{l}\text { Average for both } \\
\text { methods }\end{array}$ & $\begin{array}{l}\text { FADN national } \\
\text { data (2018) }\end{array}$ \\
\hline Average Gross return (MKD/ha) & 158,805 & 165,100 & 160,379 & 160,000 \\
\hline Average yield (kg/ha) & 7,940 & 8,255 & 8,019 & 8,000 \\
\hline Paddy rice price (MKD/kg) & 20 & 20 & 20 & 20 \\
\hline Cost of seed (MKD/ha) & 27,950 & 20,900 & 26,188 & 27,000 \\
\hline Cost of fertilizer (MKD/ha) & 11,770 & 11,138 & 11,612 & 19,200 \\
\hline $\begin{array}{l}\text { Cost of chemical protection } \\
(\mathrm{MKD} / \mathrm{ha})\end{array}$ & 11,207 & 8,189 & 10,452 & 5,535 \\
\hline $\begin{array}{l}\text { Cost for land cultivation with } \\
\text { own mechanization (MKD/ha) }\end{array}$ & 18,714 & 21,373 & 19,379 & 10,385 \\
\hline Cost of water (MKD/ha) & 8,369 & 7,439 & 8,137 & 7,200 \\
\hline Total variable costs (MKD/ha) & 78,217 & 65,013 & 71,615 & 69,320 \\
\hline Gross Margin (MKD/ha) & 80,795 & 96,062 & 84,612 & 90,680 \\
\hline $\begin{array}{l}\text { Cost for production per kg at } \\
\text { variable cost level (MKD/ha) }\end{array}$ & 10.00 & 8.59 & 10.00 & 9.00 \\
\hline $\begin{array}{l}\text { Share of variable costs from total } \\
\text { revenue }(\%)\end{array}$ & 49 & 39 & 45 & 43 \\
\hline $\begin{array}{l}\text { Share of gross margin from total } \\
\text { revenue (\%) }\end{array}$ & 51 & 58 & 53 & 57 \\
\hline
\end{tabular}

Source: field survey, 2017-2019

Unpaid labour costs as opportunity cost are excluded from the variable production costs, due to difficulties to be realistically measured. From the passports is evident that farmers rarely hire labour, since the most rely on unpaid labour force from themselves, their own family members, or unpaid neighbours and friends. Different analytical approaches exist on the pricing of unpaid farm labour. El-Osta (1996) asserts that where unpaid farm labour hours are valued at hired labour wage rates, a serious consequence is the underestimation of the cost of human time spent on the farm. Though, Katovich and Sharma (2014) state that assigning a market wage will overestimate the value of unpaid farm labour, because farmers tend to "self-exploit" and work beyond the point at which the marginal returns of their labour equal the marginal costs. According to calculation by Martinovska et al. (2012), the estimated average costs for unpaid labor in rice production accounts $13 \%$ of the total variable costs. According to this approach, the average labor costs is $9.309 \mathrm{MKD} / \mathrm{ha}$, and production costs at the variable level costs is $11 \mathrm{MKD} /$ $\mathrm{kg}$. However, the value of unpaid labor is not directly costed, and it can be considered that it is included in the net returns (gross value of production less economic costs) as a residual (El-Osta, 1996). Measurement and valuation of unpaid work (domestic and volunteer work) for different variant of sustainable rice production should be subject to specific survey.

\section{Production function}

The estimated results of econometric model of Cobb - Douglas production function are shown in the Tab. 6.

The $\mathrm{R}^{2}$ estimated shows that $59.5 \%$ of independent variables explained the dependent variable. The sum of the estimated coefficients: $\beta_{1}, \beta_{2}, \beta_{3}, \beta_{4}, \beta_{5}$, what gives information about returns to scale amounted to -0.09 . This implies that on average the rice farms have decreasing return to scale which is characteristics of stage 3 of production function. If the rice farm increases all inputs by $1 \%$, production will decrease by $0.09 \%$. This result shows that there is possibility to increase rice production through improving the use of those inputs by its slight decreasing. The value of $t=-2.24(p<0.05)$ has the highest significance for the seed material. The estimated coefficient, shown in Tab. 6, demonstrate that elasticities for mechanisation (0.06), fertilizer (0.09), pesticides (0.07) and water use (0.05) are in stage II of the production function, indicating positive decreasing function, what implies that the allocation of variables are in the rational economic stage. The calculated elasticity for seed utilization is less than 0 accounting -0.37 , what indicates positioning in the stage III 
from the production function, with negative decreasing function to the factors. This implies over-utilization of the input, since the allocation and utilization of seed are in irrational stage of production.

Table 6. Estimated results for Rice Production Function

\begin{tabular}{|l|r|r|r|r|r|}
\hline Variables & Parameters & Coefficients & Std. Error & \multicolumn{1}{c|}{$\mathrm{t}$} & Sig. $(\mathrm{p})$ \\
\hline Constant & $\beta_{0}$ & 9.71 & 0.84 & 11.50 & 0.00 \\
\hline In seed/ha & $\beta_{1}$ & -0.37 & 0.16 & -2.24 & 0.03 \\
\hline In mechanization/ha & $\beta_{2}$ & 0.06 & 0.05 & 1.24 & 0.22 \\
\hline In fertilizer/ha & $\beta_{3}$ & 0.09 & 0.07 & 1.36 & 0.18 \\
\hline In pesticides/ha & $\beta_{4}$ & 0.07 & 0.06 & 1.34 & 0.19 \\
\hline In water use/ha & $\beta_{5}$ & 0.05 & 0.05 & 1.13 & 0.26 \\
\hline Sum $\left(\beta_{1-} \beta_{5}\right)=-0.09$ & \multicolumn{7}{|l}{} \\
\hline$R^{2}=0.595$ & & & & & \\
\hline
\end{tabular}

Note: Significant at 5\% $(a=0.05)$

Source: field survey, 2017-2019, own analysis

Tab. 7 demonstrate the level of allocative efficiency of the rice farmers with sustainable rice production in the survey. The MPP, as technical efficiency, measure the change in total output associated with one additional unit of input. From the calculated results, the values of the MPP shows that farmers are most technically efficient in the use of pesticides, then utilisation of mechanised hours and fertiliser respectively. From this table can be seen that the allocative efficiency level of inputs used in sustainable rice production demonstrate that seed (-2.25) and mechanization (0.49) are overutilized since the ratio between VMP and MFC is less than 1. This implies that rice farmers could increase their output and profit by decreasing of these resources. Fertilizer, pesticides and water used are under-utilized with efficiency rate $1.27,1.15$ and 1.06 respectively, and in order to increase output and profit, farmers should increase these resources. However, the ratio for all three inputs are close to 1.0, what indicates close efficient using of these inputs. As well the VMPs are not negative indicating that rice farmers still use these resources within the economically rational range even though they were not optimally used.

Table 7. Allocative efficiency levels of inputs used in rice production

\begin{tabular}{|l|r|r|r|r|r|r|}
\hline Variables & \multicolumn{1}{|l|}{ APPP } & VMP (MPPx*Py) & MFC(Px) & \multicolumn{1}{l|}{$r=$ VMP/MFC } & Inf. \\
\hline Seed & 28.90 & -10.63 & -212.58 & 94.37 & -2.25 & $r<1$ \\
\hline Mechanization & 493.44 & 29.30 & 586.08 & $1,192.47$ & 0.49 & $r<1$ \\
\hline Fertilizer & 16.43 & 1.51 & 30.12 & 23.80 & 1.27 & $r>1$ \\
\hline Pesticides & $1,639.64$ & 122.63 & $2,452.69$ & $2,137.15$ & 1.15 & $r>1$ \\
\hline Water used & 0.61 & 0.03 & 0.66 & 0.62 & 1.06 & $r>1$ \\
\hline
\end{tabular}

Source: field survey, 2017-2019, own analysis

The MPP values for wet sowing variant (manual sowing in water) (Tab. 8) shows that farmers are most technically efficient in the use of the pesticides and mechanized hours than utilization of water, fertilizers and seed materials. The analysis of the allocative efficiency, considering this variant demonstrates that the ratio between VMP and MFC for each input is less than 1 (which implies that all inputs: seed, mechanization, fertilizer, pesticides and water are over utilized (Tab. 8). 
Table 8. Allocative efficiency levels of inputs used in rice production with wet sowing

\begin{tabular}{|l|r|r|r|r|r|r|}
\hline Variables & \multicolumn{1}{l|}{ APP } & MPP & VMP(MPPx*Py) & MFC(Px) & $r=$ VMP/MFC & Inference \\
\hline Seed & 28.03 & -13.89 & -277.81 & 92.59 & -3.00 & $r<1$ \\
\hline Mechanization & 542.91 & 42.03 & 840.64 & 1128.35 & 0.75 & $r<1$ \\
\hline Fertilizer & 16.30 & 0.71 & 14.23 & 22.50 & 0.63 & $r<1$ \\
\hline Pesticides & $1,537.16$ & 57.29 & $1,145.81$ & $2,379.65$ & 0.48 & $r<1$ \\
\hline Water used & 0.52 & 0.01 & 0.27 & 0.56 & 0.49 & $r<1$ \\
\hline \multicolumn{7}{c}{ Source: field survey, 2017-2019, own analysis }
\end{tabular}

In dry sowing variant, the results for technical efficiency of the inputs (MPP) shows that using of the pesticide is the most technically efficient while using of fertilizers, water, mechanization and seeds are less technically efficient respectively. In regards to allocative efficiency (VMP/MFC), seed material, mechanized hours and water used are over utilized, while fertilizer and pesticides are under-utilized (Tab. 9).

Table 9. Allocative efficiency levels of inputs used in rice production with dry sowing

\begin{tabular}{|l|r|r|r|r|r|r|}
\hline Variables & \multicolumn{1}{|l|}{ APP } & \multicolumn{1}{l|}{ MPP } & VMP (MPPx*Py) & MFC (Px) & $r=$ VMP/MFC & Inference \\
\hline Seed & 37.52 & -23.71 & -474.29 & 95.00 & -4.99 & $r<1$ \\
\hline Mechanization & 401.02 & -16.84 & -336.86 & $1,038.27$ & -0.32 & $r<1$ \\
\hline Fertilizer & 16.64 & 4.62 & 92.50 & 22.45 & 4.12 & $r>1$ \\
\hline Pesticides & $2,183.67$ & 257.67 & $5,153.46$ & $2,166.15$ & 2.38 & $r>1$ \\
\hline Water used & 1.07 & -0.06 & -1.26 & 0.96 & -1.31 & $r<1$ \\
\hline \multicolumn{7}{c}{ Source: field survey, 2017-2019, own analysis }
\end{tabular}

\section{CONCLUDING REMARKS}

The analyzed data show that the socioeconomic characteristics of rural households are unfavorable for achieving greater success in rice production in terms of age structure, household size and education of the household's holder. It is recommended to apply more trainings and activities for increasing of the awareness to rice farm households about technology and benefits by adapting the sustainable practices, what will lead to improved resource used, improved environmental conservation and increased family revenues, so consequently decreasing of the youth migration in this rural area.

In this study, dry seeding using seed drills instead of the manual seed broadcasting onto the watered soil showed better technological and economic results, so it is recommended when it is possible to be performed, in order to provide better productivity, higher crop density, lower seed rate, but it also enables saving water for irrigation in the initial stages of rice growing.
These positive economic effects of sustainable practices, should be an incentive for farmers to their implementation, especially when it comes to irrigation, due to water scarcity as natural resource.

In general, we can conclude that findings indicate economically rational range of using the most resources for sustainable rice production, what implies less inputs then common farmers practices, although there is still space for improvement of its optimal using. This is important for reducing the pressure to nature and preserving biodiversity in this region.

This project for introducing of sustainable practices is implemented on limited areas (16.7 ha in total), therefore it is recommended to increase these areas under the sustainable rice production, as well as to introduce practice for all farmers to keep farms evidence including economic and technological aspects. 


\section{REFERENCES}

Adedoyin, O.A., Shamsudin, N.M., Radam, A., \& Latif, A.l. (2016). Resource-Use and Allocative Efficiency of Paddy Rice Production in Mada, Malaysia. Journal of Economics and Sustainable Development, ISSN 2222-2855 (Online), Vol.7, No.1, 2016.

Agency for financial support of agriculture and rural development - AFSARD. (access to web page on 21.12.2020). Program for financial support in agriculture for 2020, http://www. ipardpa.gov.mk/Root/mak/default mak.asp.

Ali, A. (1990). Seasonal dynamics of microcrustacean and rotifer communities in Malaysian rice fields used for rice-fish farming. Springer, The International Journal of Aquatic Sciences, Hydrobiologia, 206:139-148.

Andreevska, D., Menkovska, M., \& Andov, D. (2013). Overview of the current condition, in production consumption and the research potential of the rice crop in the Republic of Macedonia. Macedonian Journal of Animal Science, Vol. 3(2), 219-228, ISSN 1857 - 6907.

Andreevska, D., Andov, D., Simeonovska, E., Dimitrovski, T., \& Ibrahim, J. (2018). Macedonian rice production nowadays - from traditional towards modern approach. International Đanakkale rice workshop, 26-27 July 2018, Danakkale, Turkey.

Angelova, K., Ilieva, V., Ruzdik, M.N., Karov, I., Mihajlov, Lj., \& Ilievski, M. (2018). Examination on yield and some yield associated parameters in different rice genotypes. Journal of Agriculture and Plant Sciences, 16(1), 21-25.

Cassman, K.G., Peng, S., Olk, D. C., Ladha, J.K., Reichardt, W., Dobermann, A., \& Singh, U. (1998). Opportunities for increased nitrogen-use efficiency for improved resource management in irrigated rice systems. Field Crops Research, 56(1-2), 7-39.

Charnes, A., Cooper, W. W., \& Rhodes, E. (1978). Measuring the efficiency of DMUs. European Journal of Operational Research, 2(6), 429-444. https://doi. org/10.1016/03772217(78)90138-8.

Chiambo, P.J., Coelho, J.P., Soares, F.B. \& Salumbo, A. (2019) Characterization of rice production system in Camacupa and Catabola municipalities of the province of Bie in Angola. Direct Research Journal of Agriculture and food science, Vol.7 (9), pp. 250-263, September 2019 ISSN 2354-4147.
Cucu, M.A., Said-Pullicino, D., Maurino, V., Bonifacio, E., Romani, M., \& Celi, L. (2014). Influence of redox conditions and rice straw incorporation on nitrogen availability in fertilized paddy soils. Biology and Fertility of Soils, 50, 755-764.

De Miranda, M.S., Fonseca, M.L., Lima, A., de Moraes, T.F., \& Rodrigues, F.A. (2015). Environmental Impacts of Rice Cultivation. American Journal of Plant Sciences, 06(12), 20092018.

Donald, P.F. (2004). Biodiversity Impacts of Some Agricultural Commodity Production Systems. Conservation Biology, 18(1), 17-38.

El-Osta, H.S., \& Ahearn, M.C. (1996). Estimating the Opportunity Cost of Unpaid Farm Labor for U.S. Farm Operators. Technical Bulletins, 156784, United States Department of Agriculture, Economic Research Service.

Elias, S., Worju, A., \& Mathewos, N. (2017). Technical efficiency of smallholder coffee farmers in Gedeo Zone, Southern Ethiopia: A stochastic frontier approach. Agricultural Science Research Journal, 7(4), 147-153.

Ferrero, A., \& Tinarelli, A. (2007). Rice Cultivation in the E.U. Ecological Conditions and Agronomical Practices. In book: Pesticide Risk Assessment in Rice Paddies, 1-24.

Goni, M., Mohammed, S., \& Baba, B.A. (2007). Analysis of Resource Use Efficiency in Rice Production in Lake Chad Area of Borno State, Nigeria. Journal of Sustainable Development in Agriculture \& Environment, 3: 31 - 37.

Grazhdaninova, M. \& Lerman, Z. (2005) Allocative and Technical Efficiency of Corporate Farms in Russia. Comparative Economic Studies, vol. 47, issue 1, 200-213.

Haque, A.H.M.M., Elazegui, F.A., Taher Mia, M.A., Kamal, M.M., \& Haque, M.M. (2012). Increase in rice yield through the use of quality seeds in Bangladesh. African Journal of Agricultural Research Vol. 7(26), pp. 3819-3827, 10 July, 2012, Available online at http://www. academicjournals.org/AJAR DOI: 10.5897/ AJAR12.541, ISSN 1991-637X 2012 Academic Journals.

Heckman, C.W. (1979). Ricefield Ecology in Northeastern Thailand. Monographiae Biologicae, Dr. W. Junk bv Publishers, Hague, $\mathrm{p}$ 228. 
Ilieva, V., Karov, I., Mihajlov, Lj., Ruzdik, M.N., \& Ilievski, M. (2014). Effect of rice moisture at harvest and rough rice storage time on milling yield and grain breakage. Scientific Works of the Institute of Agriculture - Karnobat. Vol. 3, No 1, 207-212. ISSN 1314-961X.

llieva, V., Karov, I., Mihajlov, Lj., Ruzdik, M.N., \& llievski, M. (2014). Effect of rice moisture at harvest and rough rice storage time on milling yield and grain breakage. Conference: International Scientific Conference "Breeding and Techologies Field Crops" 27-28 Nov 2014, Karnobat, Bulgaria.

Ilieva, V., Ruzdik, M.N., Karov, I., Mihajlov, Lj., Ilievski, M., \& Kovacevik, B. (2017). Genetic variability for yield and some yield-related traits in rice (Oryza sativa L.) Journal of Agriculture and Plant Sciences, 15(1/2),75-80.

Ilievski, M., Spasova, D., Mihajlov, Lj., Spasov, D., Ruzdic, M.N., llieva, V., \& Sofijanova, E. (2015). Production and balance among of cereal plants in Republic of Macedonia. Yearbook - Faculty of Agriculture, 13(1), 129-138.

Izekor, O. (2015) Production Elasticities, Return to Scale and Allocative Efficiency in Yam Production in Edo State, Nigeria. Agrosearch, 2014 Volume 14(2): 179-190, http://dx.doi. org/10.4314/agrosh.v14i2.8.

Katayma, N., Baba, Y.G., Kusumoto, Y., \& Tanaka, K. (2015). A review of post-war changes in rice farming and biodiversity in Japan. Agricultural systems, 132, 73-84.

Katoh, M., Murase, J., Hayashi, M., Matsuya, K., \& Kimura, M. (2004). Nutrient leaching from the plow layer by water percolation and accumulation in the subsoil in an irrigated paddy field. Soil Science and Plant Nutrition, 50(5), 721-729.

Katovich, E., \& Sharma, A. (2014). Costs and Returns of Grain and Vegetable Crop Production in Nepal's Mid-Western Development Region. Knowledge-based Integrated Sustainable Agriculture and Nutrition (KISAN) Project, USAID.

Konj, T.D., Mabe, F.N., \& Alhassan, H. (2019). Technical and resource-use-efficiency among smallholder rice farmers in Northern Ghana. Cogent Food \& Agriculture, 5(1), 1651473.

Liu, Y., Tang, H., Muhammad, A., Zhong, C., Li, P., Zhang, P., Yang, B., \& Huang, G. (2019). Rice Yield and Greenhouse Gas Emissions Affected by Chinese Milk Vetch and Rice Straw Retention with Reduced Nitrogen Fertilization. Agronomy
Journal, 3(6), 3028-3038.

Liu, S.Y., Zhang, Y.J., Lin, F., Zhang, L. \& Zou, J.W. (2013). Methane and Nitrous Oxide Emissions from Direct- Seeded and SeedlingTransplanted Rice Paddies in Southeast China. Plant and Soil, 374, 285-297.

Mabe, F.N., Donkoh, S.A., \& Al-hassan, S. (2018). Accounting for rice productivity heterogeneity in Ghana:The two-step stochastic metafrontier approach. International Journal of Agricultural and Biosystems Engineering, 12(8), 223-232.

Мартиновска, С.А., Георгиев, Н., Димитриевски, Д., Гошевски, Д., Аждерски, Ј., Пешевски, М., Котевска, А., Јанеска, С.И., Нацка, М., Туна, Е., \& Симоновска, А. (2012). Прирачник за подготовка на стручниот испит за проценувач за процена на вредноста на средствата во земјоделството. Факултет за земјоделски науки и храна - Скопје.

Mihov, M., Georgieva, K., \& Ivanova, N. (2017). Current problems of agricultural production mechanization. Mechanization in agriculture \& Conserving of the resources, 63(3), 111-114.

Миланов, М., \& Мартиновска, С.А. (2002) Трошоци и калкулации во земјоделството. Факултет за земјоделски науки и храна, Cкопје, стр. 331-341.

Miniotti, E.F., Romani, M., Said-Pullicino, D., Facchi, A., Bertora, C., Peyron, M., Sacco, D., Bischetti, G.B., Lerda, C., Tenni, D., Gandolfi, C., \& Celi, L. (2016). Agro-environmental sustainability of different water management practices in temperate rice agro-ecosystems. Agriculture, Ecosystems and Environment, 222, 235-248.

Младеновски, Т., Андов, Д., \& Станоев, В. (2012). Производство на сертифициран семенски материјал кај житните растенија. Земјоделски Институт, Скопје, стр.11-15.

Mogi, M. (1993). Effect of intermittent irrigation on mosquitoes (Diptera: Culicidae) and larvivorous predators in rice fields. Journal of Medical Entomology, Volume 30, Issue 2, 1 March 1993, Pages 309-319, https://doi. org/10.1093/jmedent/30.2.309.

Mottaleb, K.A., \& Mohanty, S. (2014). Farm size and profitability of rice farming under rising input costs. Journal of Land Use Science, 10(3), 243-255.

Najjuma, E., Kavoi, M.M., \& Mbeche, R. (2016). Assessment of technical efficiency of open field tomato production in Kiambu 
county, Kenya (Stochastic Frontier Approach) Jomo Kenyatta University of Agriculture and Technology JAGST Vol. 17(2) 2016, https://www. researchgate.net/publication/309396019.

Nature Conservation Programme in North Macedonia - NCP (2014). Strategy for development of tourism in the East Planning Region with Action Plan 2016-2025. Nature Conservation Programme in North Macedonia (NCP) is a project of the Swiss Agency for Development and Cooperation (SDC), coordinated by Farmahem, Skopje.

Nie, L., Peng, S., Bouman, B.A.M., Huang, J., Cui, K., Visperas, R.M., \& Xiang, J. (2009). Alleviating soil sickness caused by aerobic monocropping: responses of aerobic rice to various nitrogen sources. Soil Science and Plant Nutrition, 55(1),150-159.

Niswati, A.D. (2014). Improving Biodiversity in Rice Paddy Fields to Promote Land Sustainability. Springer, Sustainable Living with Environmental Risks pp 45-55, https://link.springer.com/ chapter/10.1007/978-4-431-54804-1_5.

Oluwatusin, F.M. (2011). Measuring Techincal Efficiency of yam farmers in Nigeria: A Stochastic Parametric Approach. Agricultural Journal, 6(2): $40-46$.

Onubuogu, G.C., Esiobu, N.S., Nwosu, C.S., \& Okereke, C.N. (2014). Resource use efficiency of smallholder cassava farmers in Owerri Agricultural zone, Imo State, Nigeria. Scholarly Journal of Agricultural Science, 4(6), 306-318.

Petri, E., \& Perdikaris, A. (2016). Rice sector in Greece. European Institution for Evolution and Integration - EIEO.

Ристески, С. (1999). Статистика за бизнис и економија. Економски факултет, Скопје.

Roger, P.A., Zimmerman, W.J., \& Lumpkin, T.A. (1993). Microbial management of wetland rice fields. In: Metting FB Jr (ed) Soil microbial ecology: applications in agricultural and environmental management. Marcel Dekker, Inc., New York, pp 417-455.

Sacco, D., Cremon, C., Zavattaro, L., \& Grignani, C. (2012). Seasonal variation of soil physical properties under different water managements in irrigated rice. Soil and Tillage Research, 118, 22-31.

Said-Pullicino, D., Cucu, M.A., Sodano, M., Birk, J.J., Glaser, B., \& Celi, L. (2014). Nitrogen immobilization in paddy soils as affected by redox conditions and rice straw incorporation.
Geoderma, 228-229, 44-53.

Simpson, I.C., Roger, P.A., Oficial, R., \& Grant, I.F. (1994) Effects of nitrogen fertilizer and pesticide management of floodwater ecology in a wetland rice field. Dynamics of microcrustaceans and dipteran larvae. Biol Fertil Soils 17: 138-146.

Singh, B., \& Singh, K.V. (2017). Fertilizer Management in Rice. Rice Production Worldwide pp 217-253, Edition: $1^{\text {st }}$, Chapter: 10, Publisher Springer International Publishing AG 2017.

Smith, P., Martino, D., Cai, Z.C., Gwary, D., Janzen, H., Kumar, P., McCarl, B., Ogle, S., O'Mara, F., Rice, C., Scholes, B., Sirotenko, O., Howden, M., McAllister, T., Pan, G.X., Romanenkov, V., Scheider, U., Towprayoon, S., Wattenbach, M. \& Smith, J. (2008). Greenhouse Gas Mitigation in Agriculture. Philosophical Transactions of the Royal Society B: Biological Sciences, 363(1492), 789-813.

Statistical Office of the Republic of North Macedonia - SSO (2008, March 1). Census of agriculture, 2007. Retrieved from http://www. stat.gov.mk

Statistical Office of the Republic of North Macedonia - SSO (2017, December 28). Structure and typology of agricultural holdings, 2016. Retrieved from http://www.stat.gov.mk

Statistical Office of the Republic of North Macedonia - SSO (2020, October 10). Statistical Yearbook of the Republic of North Macedonia, 2020. Retrieved from http://www.stat.gov.mk

Statistical Office of the Republic of North Macedonia - SSO (access 22.12.2020). MakStat database. Retrieved from http://makstat.stat. gov.mk/PXWeb/pxweb/en/MakStat.

Sun, H., Zhou, S., Fu, Z., Cheng, G., Zou, G., \& Song, X. (2016). A two-year field measurement of methane and nitrous oxide fluxes from rice paddies under contrasting climate conditions. Scientific Reports, 6(1), 28255.

Tambo, J.A., \& Gbemu, I. (2010). Resource Use Efficiency in Tomato Production in the Dangme West District, Ghana, Conference on international Research on food security, National Resource Management and Rural Development, ETH Zutith, Sept. 14 - 16.

Tam, T.N. (2016). Pesticide use in rice farming and its impacts on aquatic animals in the Mekong Delta of Vietnam. Department of Physical Geography Stockholm University, Stockholm 2016. 
Tyagi, L., Kumari, B., \& Singh, S.N. (2010). Water management - A tool for methane mitigation from irrigated paddy fields. Science of The Total Environment, 408(5), 1085-1090.
Zhao, Y., De Maio, M., Vidotto, F., \& Sacco, D. (2015). Influence of wet-dry cycles on the temporal infiltration dynamic in temperate rice paddies. Soil andTillage Research, 154, 14-21.

\title{
ВОВЕДУВАЊЕ НА ОДРЖЛИВО ПРОИЗВОДСТВО НА ОРИЗ ЗА ПОДОБРУВАЊЕ НА ЖИВОТНАТА СРЕДИНА И СОЦИО-ЕКОНОМСКИТЕ УСЛОВИ ВО КОЧАНСКИОТ РЕГИОН
}

\author{
Марија Ѓошева Ковачевиќ' ${ }^{*}$, Верица Илиева², Сашо Арсов² \\ 'Програма за зачувување на природата во Северна Македонија, Фармахем, Кичевска 1, 1060 Скопје, \\ Република Северна Македонија \\ 2 Универзитет „Гоче Делчев“, Земјоделски фракултет, Крсте Мисирков, 10-А, 2000 Штип, Република \\ Северна Македонија, \\ *Контакт автор: marija@bregalnica-ncp.mk
}

\section{Резиме}

Поволните климатски услови и долгата традиција на оризопроизводството како главен егзистенцијален извор се од основно значење голем дел од населението во Кочанската котлина да одгледува ориз. Ниското ниво на продуктивност и високите производствени трошоци се основните ограничувања во конкурентноста на пазарот, а главно поради примената на несоодветни и застарени производствени практики. Дополнително, вообичаените методи на одгледување придонесуваат кон деструкција на животната средина и агроекосистемите преку интензивно користење на природните ресурси и агрохемијата. Затоа, проектот ПЗП спроведе активности за адаптација на одржливи практики во оризопроизводството кај 30 фармери, членови на Здружението „Оризова братимка“, Чешиново, за период од 3 години (2017-2019). Пред сѐ, одржливите практики за производство на ориз применети од страна на фармерите се состоеја од: ласерско нивелирање на почвата, употреба на сертифициран семенски материјал и намалена сеидбена норма, контролирана употреба на ѓубрива и заштитни хемиски средства и контролирано користење на водата. Применети се и тестирани две варијанти на сеидба, едната со употреба на машина за сеење на сува почва, другата со рачно емитување на семе на поплавена почва. Во овој труд, податоците добиени од пасошите на фармерите за евиденција, во кои беа редовно евидентирани сите агротехнички мерки и трошоци, се обработени со користење на дескриптивни и емпириски методи на анализа. Резултатите покажуваат дека воведувањето на одржливото производство на ориз резултира со поефикасна употреба на природните ресурси и намалување на производствените трошоци, што е основно за: ублажување на небезбедноста со храна, губењето на биодиверзитетот, деградацијата на почвата и загадувањето на животната средина, и истовремено за зголемување на приходите кај руралните домаќинства.

Клучни зборови: природни ресурси, бруто маржа, Коб-Даглас производна функција, техничка ефикасност, алокативна ефикасност 